\title{
Anmeldelse:
}

\section{Den bedste verdensorden}

Af Birthe Hansen

Anders Fogh Rasmussens bog er velskrevet og letlæst med en sammenhængende vision. Den er en dansk oversættelse af en amerikansk udgave, der henvender sig til amerikanske vælgere $i$ et valgår, men udgaverne retter sig både til danskere og amerikanere. Begge parter kunne dog nok have ønsket sig en mere dybtgående behandling af nogle af de nyere og mere kontroversielle temaer.

Anders Fogh Rasmussen: Viljen til at lede. København, Politikens Forlag, 2016, $309 s$.

Viljen til at lede handler om USA's lederskab, der ifølge Anders Fogh Rasmussen (AFR) har ført til udbredelsen af frihed, demokrati og velstand. I hans vision bærer enesupermagten USA også frem over byrden og ansvaret herfor.

AFR beskriver, hvordan USA siden afslutningen på Anden Verdenskrig har ledet udviklingen af institutioner og normer, stabilitet og velstand i store dele af verden. Udgangspunktet har været den strømning i USA, der har stået fast på supermagtens pligt og muligheder internationalt. Den strømning er stærk, selv om den altid har måttet kæmpe med mere eller mindre isolationistiske tendenser,

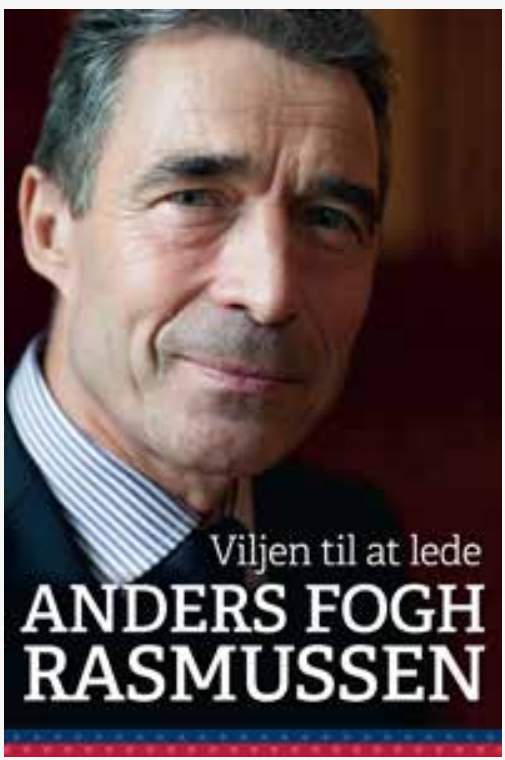

og selv om den er blevet udfordret i de senere år.

AFR nævner tre præsidenter, der hver især er eksempler på vilje og evne til engageret ledelse: Harry S. Truman, John F. Kennedy og Ronald Reagan. Truman afsluttede Anden Verdenskrig og stod for den vestlige verdens institutionalisering herefter, Kennedy klarede Cuba-krisen og gav USA selvtillid, og Reagan vandt den kolde krig. Alle havde de mod på at tage store og kontroversielle beslutninger, og alle havde de helt særlige evner for kommunikation. I bogen fungerer de

Birthe Hansen er lektor ved Institut for Statskundskab, Københavns Universitet. Hun er forfatter og medforfatter til adskillige bøger om international politik. 
både som nedslag i historien og eksempler til efterfølgelse.

De tegner også et billede af USA, når det er bedst: det vil i AFR's optik sige, når USA er villig til at engagere sig. De tre præsidenter virkede imidlertid alle under den kolde krig, og deres virke var derfor begrænset til den frie verden og til at håndtere modspillet med den sovjetisk dominerede del.

\section{Enesupermagten}

Siden 1989 har USA været enesupermagt. Det har givet muligheden for i højere grad at vælge graden af engagement. AFR fremhæver George W. Bush som den leder, der tog ansvar og inddrog USA i global problemløsning, mens Bill Clinton og Barack Obama fremstår som tøvende. Clinton, der ikke greb ind i Rwanda i 1994, "har stadig moralske ar" ifølge AFR, og Obama forholdt sig passiv i forhold til Syrien i 2011-12 samt løb fra sin røde linje, da der blev brugt kemiske våben i den syriske konflikt.

AFR krediterer Clinton og Obama for senere indsatser som reaktionen på Srebenica-massakren og konflikten i Kosovo henholdsvis luftbombardementer af det libyske luftforsvar og Gadaffis styrker i Benghazi, samt (den om end for sene) indsats mod ISIL. Hans pointe er dog, at de handlede for lidt og for sent, hvilket opmuntrer de kræfter, der "forsøger at ødelægge vores verdensorden”.

Disse kræfter anføres ifølge AFR af dels de større autokratier (Rusland og Kina), og mindre grupper og segmenter (ISIL og væbnede grupper i de ny demokratier i Mellemøsten). Derfor bør man også genoplive Robert Kagans idé om den demokratisk alliance, der kan støtte USA i fastholdelse og udbredelse af den aktuelle verdensorden. Den demokratiske allian- ce skal ikke erstatte FN, men sikre sammenholdet i og støtte Vesten.

\section{Flere spørgsmål}

Viljen til at lede er således et gennemført værdimæssigt forsvar for verdensordenen. Derfor rejser den også nogle spørgsmål:

Det første drejer sig om graden af USA's engagement. AFR har fuldstændigt ret i, at Clinton og Obama tøvede i forhold til indgriben i konflikter. Men, som AFR selv skriver, har USA en form for valgmulighed i fraværet af ligeværdige konkurrenter, og indimellem kan det måske være fornuftigt nok at hellige sig opbygningen af USA's egen ressourcebase. Fx byggede Clinton de amerikanske budgetter op efter Reagans SDI-satsning i slutningen af den kolde krig. Bush brugte derefter af overskuddet til at gøre en indsats i Mellemøsten - som Obama derefter 'betalte af' på.

Dette er ikke et argument for at bryde røde linjer eller for at forholde sig passiv, men det kan nogle gange være fornuftigt at bygge sig selv op eller være tilbageholdende, så de frihjulskørende konkurrenter ikke lægger sig i overhalingsbanen.

Det andet spørgsmål drejer sig om regningen. Skal USA selv betale gildet, eller vil europæere og andre demokrater være med, når det i øvrigt går ganske godt, og truslen forekommer langt væk? Fx er forsvaret i Danmark blevet grundigt beskåret, og den globale værnevilje synes lav. Under angrebene på Aleppo i oktober 2016 var der en demonstration foran Christiansborg. Nogle af demonstranterne blev interviewet og gav udtryk for deres sorg og vrede over angrebene. De krævede, at noget blev gjort, men ville ikke have, at der blev brugt militære midler. Omvendt er der topskatteydere, der hellere vil slippe et par pct. billigere 
end at bidrage til en dansk indsats - militær eller anden - over for internationale brændpunkter. Både venstre- og højrefløjen synes utilbøjelige til at ville engagement. Også uden for Danmark synes der at være en trang til at køre på frihjul og $\mathrm{i}$ stedet at skrabe til sig. Hvor finder AFR dem, der vil bidrage?

Det tredje spørgsmål drejer sig om vigtigheden af det personlige element i ledelse, som AFR lægger stor vægt på. Hvis man kigger på de amerikanske præsidenter efter Anden Verdenskrig er der faktisk lidt system $i$, hvad de har engageret sig i. Der synes at være et mønster i balanceringen af USA's ydre og indre kapabiliteter i forhold til graden af engagement. Dermed ikke være sagt, at ledere ikke kan gøre en forskel, og det ville have været spændende at høre lidt mere om AFR's egne erfaringer som leder.

I bogen skildres især forhandlingerne i 2002 om, hvordan russiske Kaliningrad ville blive omringet af EU-lande i forbindelse med EU-udvidelsen, hvilket kunne give store transitproblemer. Der blev imidlertid fundet en løsning, og det ville have være spændende at høre mere om forløbt af sådanne konkrete forhandlinger.

\section{USA skal holdes til ilden}

Enkelte steder er AFR ude efter akademikere, der er for USA-kritiske. Hertil må man sige - i AFR's egen ånd - at også USA skal holdes til ilden. USA er ikke blevet den supermagt, den er, uden pres - inde fra og ude fra. Som med virksomheder, der agerer på markedets vil- kår, kan det også være godt med lidt pres på USA for hele tiden at leve op til sit bedste.

USA er, som AFR skriver, den bedste enesupermagt, vi kan ønske os. Hellere en demokratisk og markedsøkonomisk lederstat end en autoritær og planøkonomisk. Ingen tvivl om det. Alligevel vil vi gerne have, at selv den bedste udvikler sig og bliver bedre, og som tiden er, med opbrud i Mellemøsten og andre 'brande', skal USA udvikle sig til at være en supermagt, der kan klare også den slags, samtidig med at man styrker sig selv i forhold til konkurrenterne - og det er en udfordring for også de allierede stater at bidrage til det fælles projekt.

Viljen til at lede handler om behovet for, at et stærkt og viljefast USA engagerer sig internationalt - også når det koster. Det er ikke så tit, at danske politikere udgiver egentlige udenrigspolitiske analyser: bogen er velskrevet, letlæst og giver en sammenhængende vision. Den er en dansk oversættelse af en amerikansk udgave, der henvender sig til amerikanske vælgere i et valgår, men udgaverne retter sig både til danskere og amerikanere. Begge parter kunne dog nok have ønsket sig en mere dybtgående behandling af nogle af de nyere og mere kontroversielle temaer. Opfølgningen kunne handle om strategier for, hvordan små stater som Danmark og deres politikere kan bidrage til, at USA udvikler sin politik og forbliver i stand til at opretholde den aktuelle verdensorden. 